\title{
MATHEMATICS
}

\author{
A.A. Aniyarov ${ }^{1}$, S.A. Jumabayev ${ }^{2}$, D.B. Nurakhmetov ${ }^{1, *}$, R.K. Kussainov ${ }^{1,3}$ \\ ${ }^{1}$ Institute of Mathematics and Mathematical Modelling, Almaty, Kazakhstan; \\ ${ }^{2}$ Institute of Management, Academy of Public Administration under the President of the Republic of Kazakhstan, \\ Nur-Sultan, Kazakhstan; \\ ${ }^{3}$ Shakarim University of Semey, Semey, Kazakhstan; \\ (E-mail: aniyarov@math.kz,Serik.Jumabayev@apa.kz,nurakhmetov@math.kz,rinat.k.kus@mail.ru)
}

\section{A hybrid algorithm for solving inverse boundary problems with respect to intermediate masses on a beam}

\begin{abstract}
The inverse problem of determining the weight of three intermediate masses on a uniform beam from the known three natural frequencies has been solved. The performed numerical analysis allows restoring the value of only the second mass in a unique way. The inverse problem of determining the weight of three intermediate masses has been solved uniquely except in the case when the first and the third masses are located geometrically symmetric relative to the middle of the beam. The hybrid algorithm for the unique solving inverse problem of determining the weight of three intermediate masses has been developed. The first three natural frequencies of the beam are calculated numerically by using the Maple computer package. Analytical relations between the masses are found.
\end{abstract}

Keywords: natural frequencies, beam equation, characteristic determinant, inverse problem, intermediate elements.

\section{Introduction}

Oscillatory systems with attached masses or attached masses and elastic couplings have been studied since the 18th century and enormous number of works were devoted to them [1-9]. In these works, mainly, problems of eigenvalues of the beam were investigated. In the listed works above, firstly, the influence on the spectrum of the geometry of the region on which the additional element is concentrated was illustrated. Secondly, the difference in the behavior of natural frequencies at large and small loads was demonstrated.

In recent years, methods of analysis of direct and inverse problems for differential operators with concentrated masses and elastic connections were actively developing [10-17]. These methods are paramount as they make it possible to develop technologies to ensure the safety of people. In contrast to works [18-22], in this paper, we develop a hybrid algorithm for solving the unique solution of the inverse problem of determining the weight of intermediate masses at points non-end of the beam from the three known natural frequencies. The novelty of this work is the geometrical symmetry of the location of the first and third masses relative to the middle of the beam for ambiguous definition of concentrated masses, which has been found on the basis of numerical calculations (see subsection 3.2).

\footnotetext{
${ }^{*}$ Corresponding author.

E-mail: nurakhmetov@math.kz
} 
The problems of diagnosing the value of one concentrated mass were investigated numerically and experimentally in $[18,19]$. Since changes in the values of concentrated masses on a beam can characterize the degree of disc frazzle, it is relevant to study mechanical systems with $n$ elements $(1<n<\infty)([20], n=2)$. The masses were found uniquely up to rearrangement of their places in [20]. The sufficient conditions for the existence of a unique solution to the problem of identifying the concentrated mass and spring stiffness at the points non-end of the beam from the known first two natural frequencies were found in [21]. The inverse problem of determining the stiffness coefficients of intermediate springs on the beam from the two known natural frequencies was solved in [22]. The conditions on the disposition of intermediate springs were found in [22] where the spring stiffness coefficients were accurately determined up to their transposition.

In this paper, a beam with three intermediate masses $m_{1}, m_{2}$, and $m_{3}(\mathrm{~kg})$ is considered. Units of measurement and abbreviations for all physical parameters considered in the article are standard.

The main goal of this work is to reveal the conditions for the geometric disposition of the concentrated masses for the nonunique solution of the inverse problem of restoring the concentrated masses with the known first three eigenfrequencies in advance.

The authors of this paper propose a hybrid algorithm that allows to calculate all three weights for concentrated masses with geometric symmetry of the location of the first and third masses relative to the middle of the beam. Note that the numerical method for solving the inverse problem allows to determine only the value of the second mass.

To solve the inverse problem, methods of the spectral theory of differential operators are applied. Justification of the proposed hybrid algorithm is carried out by using numerical calculations and analytical relationships (see subsection 3.3). The results of this study will contribute to the development of methods for solving inverse problems with multipoint internal elements.

\section{Formulation of the main problem}

Let the first mass be located at a distance $a$ from the left end of the beam, the second mass at a distance $b$, respectively, and the third mass at a distance $c$, respectively (Fig. 1). As a result, the beam is divided into 4 sections: $-\frac{l}{2}<x<a-\frac{l}{2}, a-\frac{l}{2}<x<b-\frac{l}{2}, b-\frac{l}{2}<x<c-\frac{l}{2}, c-\frac{l}{2}<x<\frac{l}{2}$.

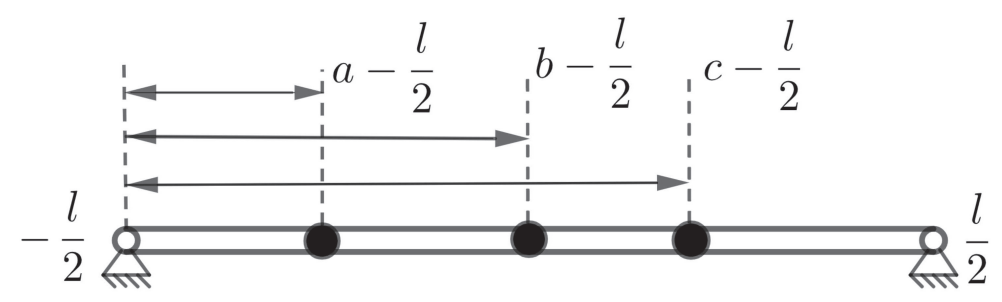

Figure 1. A beam with intermediate masses

The equation of free transverse vibrations of a beam of length $l$ at $-\frac{l}{2}<x<\frac{l}{2}, t>0$ is written as

$$
\rho A \frac{\partial^{2} w(x, t)}{\partial t^{2}}+E J \frac{\partial^{4} w(x, t)}{\partial x^{4}}=0
$$

where $w(x, t)$ is transverse displacement, $m ; \rho$ is material density, $\mathrm{kg} / \mathrm{m}^{3} ; A$ is the cross-sectional area, $\mathrm{m}^{2} ; E$ is the elastic modulus of material, $N / m^{2} ; J$ is the moment of inertia of the beam cross-section, $m^{4}$.

We use a method that is also applicable to beams with different types of fixation. For definiteness, we consider only a hinged-hinged beam. The problem of transverse vibrations of a beam of length $l$ by replacement $w(x, t)=y(x) \sin (\omega t)$ is reduced to the following spectral problem:

$$
\begin{gathered}
E J y^{I V}(x)=\omega^{2} \rho A y(x), \quad x \neq a-\frac{l}{2}, x \neq b-\frac{l}{2}, x \neq c-\frac{l}{2}, \\
{\left[E J y^{\prime \prime \prime}(x)\right]_{x=P_{i}}=-m_{i} \omega^{2} y\left(P_{i}\right), \quad i=1,2,3 .} \\
{[y(x)]_{x=P_{i}}=0, \quad\left[E y^{\prime}(x)\right]_{x=P_{i}}=0, \quad\left[E J y^{\prime \prime}(x)\right]_{x=P_{i}}=0,}
\end{gathered}
$$




$$
\begin{gathered}
\left.y(x)\right|_{x=-\frac{l}{2}}=0,\left.\quad E J y^{\prime \prime}(x)\right|_{x=-\frac{l}{2}}=0, \\
\left.y(x)\right|_{x=\frac{l}{2}}=0,\left.\quad E J y^{\prime \prime}(x)\right|_{x=\frac{l}{2}}=0,
\end{gathered}
$$

where $P_{1}=a-\frac{l}{2}, P_{2}=b-\frac{l}{2}, P_{3}=c-\frac{l}{2}$ and

$$
[f(x)]_{x=c}=\lim _{\varepsilon \rightarrow+0}[f(c-\varepsilon)-f(c+\varepsilon)] .
$$

It means the jump of the function at the point $x=c$. Denote $p^{4}=\frac{\omega^{2} \rho A}{E J}$, where $\omega$ is frequency parameter, Hz.

\section{Material and methods}

This section describes the main methods for solving the inverse problem of determining the concentrated masses from three known natural frequencies of the hinged-hinged Euler-Bernoulli beam. For this, it is necessary to write down an explicit form of the characteristic determinant of problem (1)-(5), which is important for calculating the first three natural frequencies. Then, we obtain a system of three nonlinear equations with three unknowns by using the known first three natural frequencies and the explicit form of the characteristic determinant. To find the physical parameters of the concentrated masses, the Maple computer package is used [23]. Some explicit relationships between the masses are found with the help of recurrent transformations, which are confirmed by numerical calculations.

\subsection{The problem of transverse vibrations of a beam with intermediate masses}

To calculate the natural frequencies of problem (1)-(5), an explicit form of the characteristic determinant is required. Let us formulate the main lemma.

Lemma 1. The values of the natural frequencies of problem (1)-(5) are determined from the equation

$$
\begin{gathered}
\Delta\left(a, b, c, l, p, m_{1}, m_{2}, m_{3}\right)=\alpha(a, b, c, l, p) m_{1} m_{2} m_{3}+\beta_{1}(a, b, l, p) m_{1} m_{2}+ \\
+\beta_{2}(a, c, l, p) m_{1} m_{3}+\beta_{3}(a, b, l, p) m_{2} m_{3}+\gamma_{1}(a, l, p) m_{1}+ \\
+\gamma_{2}(b, l, p) m_{2}+\gamma_{3}(c, l, p) m_{3}+\Delta_{0}(l, p)=0
\end{gathered}
$$

where

$$
\begin{gathered}
\alpha(a, b, c, l, p)=-\frac{p^{3}}{\rho^{3} A^{3}}(2(\sin (p(a+b-l))+\sin (p(a-b+l)))(\cosh (p(a-b+l))-\cosh (p(a+b-l)))+ \\
+2(\sin (p(b+c-l))-\sin (p(b-c+l)))(\cosh (p(b+c-l))-\cosh (p(b-c+l)))+ \\
+2(\cos (p(a+b-l))-\cos (p(a-b+l)))(\sinh (p(a-b+l))+\sinh (p(a+b-l)))+ \\
+2(\cos (p(b+c-l))-\cos (p(b-c+l)))(\sinh (p(b-c+l))-\sinh (p(b+c-l)))+ \\
+2(\cos (p(b+c-l))-\cos (p(b-c+l)))(\sinh (p(2 a-b+c-l))-\sinh (p(2 a-b-c+l)))+ \\
+2(\cos (p(a-b+l))-\cos (p(a+b-l)))(\sinh (p(a+b-2 c+l))+\sinh (p(a-b+2 c-l)))+ \\
+2(\cosh (p(a+b-l))-\cosh (p(a-b+l)))(\sin (p(a+b-2 c+l))+\sin (p(a-b+2 c-l)))+ \\
+2(\cosh (p(b-c+l))-\cosh (p(b+c-l)))(\sin (p(2 a-b+c-l))-\sin (p(2 a-b-c+l)))+ \\
+\sin (p(2 a-l))(\cosh (p(2 b-l))+\cosh (p(2 c-l)))+\sin (p(2 b-l))(\cosh (p(2 a-l))-\cosh (p(2 c-l)))- \\
-\sin (p(2 c-l))(\cosh (p(2 a-l))+\cosh (p(2 b-l)))+\cos (p(2 a-l))(\sinh (p(2 c-l))-\sinh (p(2 b-l)))+ \\
+\cos (p(2 b-l))(\sinh (p(2 c-l))-\sinh (p(2 a-l)))+\cos (p(2 c-l))(\sinh (p(2 b-l))-\sinh (p(2 a-l)))+ \\
+\sin (p(2 a-2 b+l))(\cosh (p l)-\cosh (p(2 c-l)))+\sin (p(2 a-2 c+l))(\cosh (p l)-\cosh (p(2 b-l)))+ \\
+\sin (p(2 b-2 c+l))(\cosh (p l)-\cosh (p(2 a-l)))+\sinh (p(2 a-2 b+l))(\cos (p(2 c-l))-\cos (p l))+ \\
+\sinh (p(2 a-2 c+l))(\cos (p(2 b-l))-\cos (p l))+\sinh (p(2 b-2 c+l))(\cos (p(2 a-l))-\cos (p l))+ \\
+2(\sinh (p(2 a-l))-\sinh (p(2 c-l))) \cos (p l)+2(\sin (p(2 c-l))-\sin (p(2 a-l))) \cosh (p l)+ \\
+2(\cosh (p(2 b-l))-\cosh (p l)) \sin (p l)+2(\cos (p l)-\cos (p(2 b-l))) \sinh (p l)- \\
\quad-(\cosh (p(2 a-2 b+l))+\cosh (p(2 b-2 c+l))-\cosh (p(2 a-2 c+l))) \sin (p l)+ \\
\quad+(\cos (p(2 a-2 b+l))+\cos (p(2 b-2 c+l))-\cos (p(2 a-2 c+l))) \sinh (p l)+ \\
\quad+\cosh (p(2 a-2 b+2 c-l)) \sin (p l)-\cos (p(2 a-2 b+2 c-l)) \sinh (p l)) \\
\end{gathered}
$$




$$
\begin{aligned}
& \beta_{1}(a, b, l, p)=-\frac{1}{\rho^{2} A^{2}}\left(4 p^{2}(\sin (p l) \sinh (p(2 a-2 b+l))-\sinh (p l) \sin (p(2 a-2 b+l))+\right. \\
& +(\cos (p l)-\cos (p(2 b-l))) \cosh (p(2 a-l))+(\cos (p l)-\cos (p(2 a-l))) \cosh (p(2 b-l))+ \\
& +(\sinh (p(2 b-l))-\sinh (p(2 a-l))) \sin (p l)+(\sin (p(2 a-l))-\sin (p(2 b-l))) \sinh (p l)+ \\
& +2(\cos (p(a-b+l))-\cos (p(a+b-l))) \cosh (p(a-b+l))+ \\
& +2(\cos (p(a+b-l))-\cos (p(a-b+l))) \cosh (p(a+b-l))+ \\
& +(\cos (p(2 a-l))+\cos (p(2 b-l))) \cosh (p l)-2 \cosh (p l) \cos (p l))), \\
& \beta_{2}(a, c, l, p)=-\frac{1}{\rho^{2} A^{2}}\left(4 p^{2}(\sinh (p l) \sin (p(2 a-2 c+l))-\sin (p l) \sinh (p(2 a-2 c+l))+\right. \\
& +(\cosh (p(2 a-l))-\cosh (p l)) \cos (p(2 c-l))+(\cosh (p(2 c-l))-\cosh (p l)) \cos (p(2 a-l))+ \\
& +(\sinh (p(2 a-l))-\sinh (p(2 c-l))) \sin (p l)+(\sin (p(2 c-l))-\sin (p(2 a-l))) \sinh (p l) \\
& +2(\cosh (p(a+c-l))-\cosh (p(a-c+l))) \cos (p(a-c+l))+ \\
& +2(\cosh (p(a-c+l))-\cosh (p(a+c-l))) \cos (p(a+c-l))- \\
& -(\cosh (p(2 a-l))+\cosh (p(2 c-l))) \cos (p l)+2 \cosh (p l) \cos (p l))), \\
& \beta_{3}(b, c, l, p)=-\frac{1}{\rho^{2} A^{2}}\left(4 p^{2}(\sin (p l) \sinh (p(2 b-2 c+l))-\sinh (p l) \sin (p(2 b-2 c+l))+\right. \\
& +(\cos (p l)-\cos (p(2 c-l))) \cosh (p(2 b-l))+(\cos (p l)-\cos (p(2 b-l))) \cosh (p(2 c-l))+ \\
& +(\sinh (p(2 c-l))-\sinh (p(2 b-l))) \sin (p l)+(\sin (p(2 b-l))-\sin (p(2 c-l))) \sinh (p l)+ \\
& +2(\cos (p(b-c+l))-\cos (p(b+c-l))) \cosh (p(b-c+l))+ \\
& +2(\cos (p(b+c-l))-\cos (p(b-c+l))) \cosh (p(b+c-l))- \\
& +(\cos (p(2 b-l))+\cos (p(2 c-l))) \cosh (p l)-2 \cosh (p l) \cos (p l))) \text {, } \\
& \gamma_{1}(a, l, p)=\frac{16 p}{\rho A}((\cosh (p l)-\cosh (p(2 a-l))) \sin (p l)+(\cos (p l)-\cos (p(2 a-l))) \sinh (p l)), \\
& \gamma_{2}(b, l, p)=-\frac{16 p}{\rho A}((\cosh (p l)-\cosh (p(2 b-l)) \sin (p l)+(\cos (p l)-\cos (p(2 b-l))) \sinh (p l)), \\
& \gamma_{3}(c, l, p)=-\frac{16 p}{\rho A}((\cosh (p l)-\cosh (p(2 c-l))) \sin (p l)+(\cos (p l)-\cos (p(2 c-l))) \sinh (p l)), \\
& \Delta_{0}(l, p)=-64 \sin (p l) \sinh (p l) .
\end{aligned}
$$

Here $\Delta_{0}(l, p)$ is the characteristic determinant without masses. To find $\omega$ the vibration frequencies from relation (6), the values $p$ are first determined and then we find $\omega=\sqrt{\frac{E J}{\rho A}} p^{2}$.

The proof of this lemma is carried out similarly to the method of in [22], and checking it is easy. To limit the volume of the paper, we present only a scheme for the proof of Lemma 1.

The scheme of the proof:

1. Let us write the fundamental systems solving equation (1) in four intervals.

2. We construct the solution of equation (1) on four intervals, which contain 16 constants.

3. Further, it is required that the solution of equation (1) satisfies the internal conditions (2), (3), and the boundary conditions (4), (5). Thus, we obtain a system of homogeneous nonlinear equations.

4. A priory for the existence of natural frequencies, it is necessary that the determinant of the resulting system of nonlinear equations is equal to zero.

\subsection{Numerical calculations}

In this subsection, a series of numerical calculations are carried out to reconstruct the quantity of the concentrated masses from the known first three natural frequencies. The experimental model consists of a steel beam with a radius of $0.01 \mathrm{~m}$, a length of $6 \mathrm{~m}$ and simply supported at the ends. Then $E J=1649.34\left(\mathrm{Nm}^{2}\right)$, $\rho=7800\left(\mathrm{~kg} \mathrm{~m}^{-3}\right), A=3.14 \cdot 10^{-4}\left(\mathrm{~m}^{2}\right)$. 
Determination of the quantity of the masses from the known first three natural frequencies

\begin{tabular}{|c|c|c|c|c|c|c|c|c|}
\hline$\omega_{1}$ & $\omega_{2}$ & $\omega_{3}$ & $a$ & $b$ & $c$ & $m_{1}$ & $m_{2}$ & $m_{3}$ \\
\hline 6.796 & 27.355 & 63.587 & 2 & 3 & 4 & 0.499 & 0.1 & 0.3 \\
& & & & & & 0.3 & 0.1 & 0.499 \\
6.926 & 27.35 & 60.08 & 1 & 3 & 5 & 0.5 & 0.2 & 0.299 \\
& & & & & & 0.299 & 0.2 & 0.5 \\
6.9 & \multirow{2}{*}{27.737} & \multirow{2}{*}{61.477} & \multirow{2}{*}{1.3} & \multirow{2}{*}{3.7} & 0.149 & 0.299 & 0.25 \\
& & & & & & 0.25 & 0.299 & 0.149 \\
\hline
\end{tabular}

T a ble 2

Determination of the quantity of the masses from the known first three natural frequencies

\begin{tabular}{|c|c|c|c|c|c|c|c|c|}
\hline$\omega_{1}$ & $\omega_{2}$ & $\omega_{3}$ & $a$ & $b$ & $c$ & $m_{1}$ & $m_{2}$ & $m_{3}$ \\
\hline 6.799 & 27.308 & 63.799 & 2 & 2.5 & 4 & 0.3 & 0.1 & 0.499 \\
& & & & & & 0.433 & 0.099 & 0.366 \\
6.801 & 27.282 & 63.925 & 2 & 3.7 & 4 & 0.3 & 0.099 & 0.5 \\
& & & & & & 0.585 & 0.1 & 0.215 \\
6.982 & 27.228 & \multirow{2}{*}{60.863} & \multirow{2}{*}{4} & 5 & 5 & 0.299 & 0.1 & 0.5 \\
& & & & & & 0.344 & 0.1 & 0.454 \\
\hline
\end{tabular}

Table 3

Determination of the quantity of the masses from the known first three natural frequencies

\begin{tabular}{|c|c|c|c|c|c|c|c|c|}
\hline$\omega_{1}$ & $\omega_{2}$ & $\omega_{3}$ & $a$ & $b$ & $c$ & $m_{1}$ & $m_{2}$ & $m_{3}$ \\
\hline 6.785 & 27.459 & 63.479 & 2.2 & 3 & 4 & 0.3 & 0.099 & 0.499 \\
& & & & & & -0.162 & 0.139 & 0.953 \\
6.827 & 27.178 & 63.170 & 2 & 3 & 4.3 & 0.299 & 0.099 & 0.5 \\
\hline
\end{tabular}

The results of numerical calculations illustrate that the geometrical arrangement of the first and third masses plays an important role in the ambiguous reconstruction of these quantities. It follows from Tables 1, 2 that the symmetrical arrangement of the first and third masses relative to the middle of the beam leads to ambiguous restoration of the values of these masses. Note that the location of the second mass between the first and third has no significant effect. It can be seen from Table 3 that the violation of symmetry with respect to the middle of the beam when the masses are located makes it possible to restore the values of all three masses uniquely. We calculate the natural frequencies of problem (1)-(5) with an accuracy of $\varepsilon=10^{-6}$. Here $\varepsilon$ means that for fixed values of $a, b, c, l, m_{1}, m_{2}, m_{3}$ condition $\left|\Delta\left(a, b, c, l, m_{1}, m_{2}, m_{3}\right)\right|<\varepsilon, i=1,2,3$ is satisfied.

\section{3 $A$ relationship between the concentrated masses}

It follows from tables 1-3 that the second mass is determined uniquely regardless of the geometric location. Therefore, in this section, the analytical relationships of the first and third masses between the second mass are shown.

Consider the inverse problem for determining the values of the mass. Assume that we know all the physical parameters, the location of the intermediate masses, as well as the first three natural frequencies of the transverse vibrations of the beam. It is required to determine the value of the first and third mass. Here, we assume that the second mass is uniquely determined numerically; therefore, the parameter is assumed to be known.

Lemma 2. The parameters $m_{1}$ and $m_{3}$ are determined by the following formulas, respectively:

If $b_{m_{1}}<0$, then

$$
m_{1}=-\frac{2 c_{m_{1}}}{b_{m_{1}}-\sqrt{b_{m_{1}}^{2}-4 a_{m_{1}} c_{m_{1}}}}, \quad m_{3}=-\frac{a_{2} m_{1} m_{2}+a_{5} m_{1}+a_{6} m_{2}+a_{8}}{a_{1} m_{1} m_{2}+a_{3} m_{1}+a_{4} m_{1}+a_{7}}
$$

If $b_{m_{1}} \geq 0$, then

$$
m_{1}=-\frac{2 c_{m_{1}}}{b_{m_{1}}+\sqrt{b_{m_{1}}^{2}-4 a_{m_{1}} c_{m_{1}}}}, \quad m_{3}=-\frac{a_{2} m_{1} m_{2}+a_{5} m_{1}+a_{6} m_{2}+a_{8}}{a_{1} m_{1} m_{2}+a_{3} m_{1}+a_{4} m_{1}+a_{7}}
$$


where

$$
\begin{aligned}
& a_{m_{1}}=\left(a_{1} b_{2}-a_{2} b_{1}\right) m_{2}^{2}+\left(a_{1} b_{5}-a_{2} b_{3}+a_{3} b_{2}-a_{5} b_{1}\right) m_{2}-b_{3} a_{5}+b_{5} a_{3}, \\
& b_{m_{1}}=\left(a_{1} b_{6}-a_{2} b_{4}+a_{4} b_{2}-a_{6} b_{1}\right) m_{2}^{2}-a_{8} b_{3}+b_{5} a_{7}-b_{7} a_{5}+b_{8} a_{3}+ \\
& +\left(a_{1} b_{8}-a_{2} b_{7}+a_{3} b_{6}+a_{4} b_{5}-a_{5} b_{4}-a_{6} b_{3}+a_{7} b_{2}-a_{8} b_{1}\right) m_{2}, \\
& c_{m_{1}}=\left(a_{4} b_{6}-a_{6} b_{4}\right) m_{2}^{2}+\left(a_{4} b_{8}-a_{6} b_{7}+a_{7} b_{6}-a_{8} b_{4}\right) m_{2}-a_{8} b_{7}+a_{7} b_{8} .
\end{aligned}
$$

Proof of Lemma 2. Let $p_{1}, p_{2}$ and $p_{3}$ be zeros of $\Delta(p):=\Delta\left(a, b, c, l, p, m_{1}, m_{2}, m_{3}\right)$. Then, three equalities hold

$$
\left\{\begin{array}{l}
a_{1} m_{1} m_{2} m_{3}+a_{2} m_{1} m_{2}+a_{3} m_{1} m_{3}+a_{4} m_{2} m_{3}+a_{5} m_{1}+a_{6} m_{2}+a_{7} m_{3}+a_{8}=0 \\
b_{1} m_{1} m_{2} m_{3}+b_{2} m_{1} m_{2}+b_{3} m_{1} m_{3}+b_{4} m_{2} m_{3}+b_{5} m_{1}+b_{6} m_{2}+b_{7} m_{3}+b_{8}=0 \\
c_{1} m_{1} m_{2} m_{3}+c_{2} m_{1} m_{2}+c_{3} m_{1} m_{3}+c_{4} m_{2} m_{3}+c_{5} m_{1}+c_{6} m_{2}+c_{7} m_{3}+c_{8}=0
\end{array}\right.
$$

Here

$$
\begin{aligned}
& a_{1}=\alpha\left(a, b, c, l, p_{i}\right), \quad a_{2}=\beta_{1}\left(a, b, l, p_{i}\right), \quad a_{3}=\beta_{2}\left(a, c, l, p_{i}\right), \quad a_{4}=\beta_{3}\left(b, c, l, p_{i}\right), \\
& a_{5}=\gamma_{1}\left(a, l, p_{i}\right), \quad a_{6}=\gamma_{2}\left(b, l, p_{i}\right), \quad a_{7}=\gamma_{3}\left(c, l, p_{i}\right), \quad a_{8}=\Delta_{0}\left(l, p_{i}\right), \quad i=1 .
\end{aligned}
$$

Similar designations are valid for $b_{k}, c_{k}, k=\overline{1,8}$ for $i=2,3$, respectively. We transform the system of nonlinear equations (9) into the following form

$$
\left\{\begin{array}{l}
\left(a_{1} m_{1} m_{2}+a_{3} m_{1}+a_{4} m_{2}+a_{7}\right) m_{3}+a_{2} m_{1} m_{2}+a_{5} m_{1}+a_{6} m_{2}+a_{8}=0 \\
\left(b_{1} m_{1} m_{2}+b_{3} m_{1}+b_{4} m_{2}+b_{7}\right) m_{3}+b_{2} m_{1} m_{2}+b_{5} m_{1}+b_{6} m_{2}+b_{8}=0 . \\
\left(c_{1} m_{1} m_{2}+c_{3} m_{1}+c_{4} m_{2}+c_{7}\right) m_{3}+c_{2} m_{1} m_{2}+c_{5} m_{1}+c_{6} m_{2}+c_{8}=0
\end{array}\right.
$$

Using a linear combination from system (10), we obtain a quadratic equation with respect to $m_{1}$ :

$$
\begin{aligned}
& \left(\left(a_{1} b_{2}-a_{2} b_{1}\right) m_{2}^{2}+\left(a_{1} b_{5}-a_{2} b_{3}+a_{3} b_{2}-a_{5} b_{1}\right) m_{2}-b_{3} a_{5}+b_{5} a_{3}\right) m_{1}^{2}+ \\
& \quad+\left(\left(a_{1} b_{6}-a_{2} b_{4}+a_{4} b_{2}-a_{6} b_{1}\right) m_{2}^{2}-a_{8} b_{3}+b_{5} a_{7}-b_{7} a_{5}+b_{8} a_{3}+\right. \\
& \left.+\left(a_{1} b_{8}-a_{2} b_{7}+a_{3} b_{6}+a_{4} b_{5}-a_{5} b_{4}-a_{6} b_{3}+a_{7} b_{2}-a_{8} b_{1}\right) m_{2}\right) m_{1}+ \\
& +\left(a_{4} b_{6}-a_{6} b_{4}\right) m_{2}^{2}+\left(a_{4} b_{8}-a_{6} b_{7}+a_{7} b_{6}-a_{8} b_{4}\right) m_{2}-a_{8} b_{7}+a_{7} b_{8}=0
\end{aligned}
$$

Let $b_{m_{1}}<0$. Then the corresponding solution to a quadratic equation of the form $a x^{2}+b x+c=0$ is defined as

$$
x=\frac{-2 c}{b-\sqrt{b^{2}-4 a c}}
$$

which is used in Muller's method. Using formula (12) for the quadratic equation (11), we obtain the first formula from (7). After finding $m_{1}$, the second formula of (7) follows from (10). For the case $b_{m_{1}} \geq 0$, the proof of (8) is similar. Lemma 2 is proved.

\subsection{The hybrid algorithm for solving the uniqueness of the inverse problem}

Subsections 3.2 and 3.3 allow to formulate the hybrid algorithm for solving the uniqueness of the inverse problem of three concentrated masses from the known first three natural frequencies.

Hybrid algorithm:

1. All physical parameters of the beam are fixed, except concentrated masses.

2. The parameters of the first three natural frequencies are entered.

3. The value of $m_{2}$ is numerically found.

4. Using formula (7), we find $m_{1}$ and $m_{3}$.

To test the proposed hybrid algorithm, consider an example.

1. The experimental model consists of a steel beam with the radius of $0.01 \mathrm{~m}$, the length of $6 \mathrm{~m}$ and the hinged fixation at the end. Then $E J=1649.34\left(\mathrm{Nm}^{2}\right), \rho=7800\left(\mathrm{~kg} \mathrm{~m}^{-3}\right), A=3.14 \cdot 10^{-4}\left(\mathrm{~m}^{2}\right)$. The masses $m_{1}, m_{2}$, and $m_{3}$ are located from the left end of the beam at distances of $2 \mathrm{~m}, 3 \mathrm{~m}$, and 4 m, respectively.

2. $\omega_{1}=6,796, \quad \omega_{2}=27,355, \quad \omega_{3}=63,587$.

3. $m_{2}=0,1$.

4. $m_{1}=0,3, \quad m_{3}=0,499$. 
The considered example confirms the validity of the proposed hybrid algorithm. Note that for the proposed algorithm the geometrical disposition of the concentrated masses does not matter. In the future, the practical interest will be to investigate the inverse problem for a beam with a variable foundation coefficient when the beam comprises some concentrated elements. The beams with the variable foundation coefficient without concentrated masses for various fixations were investigated in [24].

\section{Conclusion}

It can be concluded that for solving the inverse problem regarding intermediate masses on the beam, the geometric symmetry of the location of the first and third masses relative to the middle of the beam is essential based on the performed numerical calculations (see Table 1,2). The numerical analysis allows restoring uniquely the value of the second mass, regardless of its location (see Table 3). The last formulated fact allowed us to find the analytical relationships of the first and third masses between the second. We have developed the hybrid algorithm for solving inverse problems for determining the weight of intermediate masses on a uniform beam from the known first three natural frequencies based on the revealed patterns. Our results can be useful for the development of methods of inverse problems in beam systems with attached elements.

\section{Acknowledgments}

The authors acknowledge the financial support provided by the Ministry of Education and Science of the Republic of Kazakhstan (project AP08052239).

\section{References}

1 Крылов А.Н. О некоторых дифференциальных уравнениях математической физики, имеющих приложение в технических вопросах / А.Н. Крылов. - Л.: Изд. АН СССР, 1932. - 472 с.

2 Гантмахер Ф.Р. Осцилляционные матрицы и ядра и малые колебания механических систем / Ф.Р. Гантмахер, М.Г. М. Крейн. - М.: Гос. изд-во тех.-теор. лит-ры, 1950. - 359 с.

3 Головатый Ю.Д. Спектральные свойства колебательных систем с присоединенными массами / Ю.Д. Головатый // Тр. ММО. - 1992. - Т. 54. - С. 29-72.

4 Вибрация в технике: Справоч. - Т. 1 / под ред. В.В. Болотина. - М.: Машиностроение, $1978 .-352$ c.

5 Коллатц Л. Задачи на собственные значения / Л. Коллатц. - М.: Наука, 1968. - 504 с.

6 Low K.H. On the eigenfrequencies for mass loaded beams under classical boundary conditions / K.H. Low // Journal of Sound and Vibration. - 1998. - 215. - No 2. - P. 381-389.

7 Low K.H. Comparisons of experimental and numerical frequencies for classical beams carrying a mass in-span / K.H. Low // International Journal of Mechanical Sciences. - 1999. - 41. - P. 1515-153.

8 Low K.H. On the methods to derive frequency equations of beams carrying multiple masses / K.H. Low // International Journal of Mechanical Sciences. - 2001. - 43. - P. 871-881.

9 Low K.H. Natural frequencies of a beam-mass system in transverse vibration: Rayleigh estimation versus eigenanalysis solutions / K.H. Low // International Journal of Mechanical Sciences. - 2003. - 45. P. 981-993.

10 Gürgöze M. On the effect of an attached spring-mass system on the frequency spectrum of a cantilevered beam / M. Gürgöze, H.M. Batan // Journal of Sound and Vibration. - 1996. - 195. - No. 1. - P. $163-168$.

11 Meirovitch L. Fundamentals of vibrations / L. Meirovitch. - McGraw-Hill Book Co-Singapore. International Edition, 2001. - 826 p.

12 Ватульян А.О. Обратные задачи в механике деформируемого твердого тела / А.О. Ватульян. - М.: Физматлит, 2007. - 224 с.

13 Yong L. An analytical model for dynamic response of beam-column frames to impulsive ground excitations / L. Yong, G. Shunfeng // Int. Journal of Solids and Structures. - 2007. - 44. - P. 779-798.

14 Гладвелл Г.М.Л. Обратные задачи теории колебаний / Г.М.Л. Гладвелл. - М.: Ижевск: НИЦ «Регулярная и хаотическая динамика»; Институт компьютерных исследований, 2008. - 608 с. 
15 Younis M.I. MEMS Linear and Nonlinear Statics and Dynamics / M.I.Younis - Springer New York Dordrecht Heidelberg London, 2011. - 454 p.

16 Banerjee J.R. Free vibration of beams carrying spring-mass systems - A dynamic stiffness approach / J.R. Banerjee // Computers and Structures. - 2012. - 104-105. - P. 21-26.

17 Wang Z. Analytical and experimental study of free vibration of beams carrying multiple masses and springs / Z. Wang, M. Hong, J. Xu, H. Cui // J. Marine Sci. Appl. - 2014. - 13. - P. 32-40.

18 Morassi A. On point mass identification in rods and beams from minimal frequency measurements / A. Morassi, M. Dilena // Inverse Problems in Engineering. - 2002. - 10. - P. 183-201.

19 Ахтямов А.М. Идентификация точечной массы на стержне / А.М. Ахтямов, А.Р. Аюпова // Дефектоскопия. - 2013. - 49. - № 10. - С. 26-33.

20 Ахтямов А.М. Диагностирование двух масс, сосредоточенных на балке / А.М. Ахтямов, А.Р. Аюпова // Приборы и системы. Управление, контроль, диагностика. - 2010. - № 1. - С. 42-44.

21 Кангужин Б.Е. Идентификация сосредоточенной массы и жесткости пружины на стержне / Б.Е. Кангужин, Д.Б. Нурахметов // Электрон. журн. «Техническая акустика». - 2015. - 15. - № 9. - С. 1-9.

22 Nurakhmetov D.B. Inverse boundary problems for intermediate springs on a rod with geometrical symmetiry / D.B. Nurakhmetov, S.A. Jumabayev, A.A. Aniyarov // Electronic Journal of Differential Equations. - 2017. - 2017 (2017). - No. 33. - P. 1-10.

23 Hunt B.R. Differential Equations with Maple / B.R. Hunt, L.J. Lardy, R.L. Lipsman, J.E. Osborn, J.M. Rosenberg. John Wiley and Sons, Inc., 2009. - 264 p.

24 Nurakhmetov D.B. Symmetric properties of eigenvalues and eigenfunctions of uniform beams / D.B. Nurakhmetov, S.A. Jumabayev, A.A. Aniyarov, R.K. Kussainov // Symmetry. - 2020. - 12. - No. 12:2097. - P. 1-13.

\author{
А.А. Анияров ${ }^{1}$, С.А. Джумабаев ${ }^{2}$, Д.Б. Нұрахметов ${ }^{1}$, Р.К. Құсаинов ${ }^{1,3}$ \\ ${ }^{1}$ Математика және математикалық, модельдеу институты, Алматы, Қазақстан; \\ ${ }^{2}$ Қазақ,стан Республикасы Президентінін, жанындавы \\ Мемлекеттік басқару академиясы, Нұр-Сұлтан, Қазақстан; \\ ${ }^{3}$ Семей қзаласынын, Шәкәрім атындавы университеті, Семей, Қазақсттан
}

\title{
Бөренедегі аралық массаларға қатысты шекаралық кері есептерді шешуге гибридті алгоритм туралы
}

\begin{abstract}
Белгілі үш жиілікпен біртекті бөренедегі үш аралық массаның салмақтарын анықтайтын кері есеп шешілді. Жүргізілген сандық есептеулер тек қана екінші массаның салмағын анықтауға мүмкіндік береді. Бөренедегі үш аралық массаның салмақтарын анықтайтын кері есеп бірінші мен екінші масса бөрененің ортасына қатысты геометриялық симметриялы орналасқан жағдайдан басқа жағдайларда бірмәнді шешіледі. Барлық үш аралық массаның салмақтарын анықтайтын кері есептің бірмәнді шешімі бар болуы үшін гибридті алгоритм жасалды. Алғашқы үш меншікті жиілік Марlе компьютерлік пакеті арқылы есептелді. Массалар арасында аналитикалық қатынас табылды.
\end{abstract}

Kілт сөздер: меншікті жиіліктер, бөрене теңдеуі, сипаттамалық анықтауыш, кері есеп, аралық элементтер. 


\author{
А.А. Анияров ${ }^{1}$, С.А. Джумабаев ${ }^{2}$, Д.Б. Нурахметов ${ }^{1}$, P.К. Кусаинов ${ }^{1,3}$ \\ ${ }^{1}$ Институт математики и математического моделирования, Алматъ, Казахстан; \\ ${ }^{2}$ Академия государственного управления при Президенте Республики Казахстан, Нур-Султан, Казахстан; \\ ${ }^{3}$ Университет имени Шакарима города Семей, Семей, Казахстан
}

\title{
Об одном гибридном алгоритме решения обратных граничных задач относительно промежуточных масс на балке
}

\begin{abstract}
Решена обратная задача определения веса трех промежуточных масс на однородной балке по известным трем собственным частотам. Проведенный численный анализ позволяет единственным образом восстанавливать величину только второй массы. Обратная задача определения веса трех промежуточных масс решается однозначно, кроме случая, когда первая и третья массы расположены геометрически симметрично относительно середины балки. Для однозначного решения обратной задачи определения веса трех промежуточных масс разработан гибридный алгоритм. Первые три собственные частоты стержня вычислены численно с помощью компьютерного пакета Марle. Найдено аналитическое соотношение между массами.
\end{abstract}

Ключевые слова: собственные частоты, уравнение балки, характеристический определитель, обратная задача, промежуточные элементы.

\section{References}

1 Krylov, A.N. (1932). O nekotorykh differentsialnykh uravneniakh matematicheskoi fiziki, imeushchikh prilozhenie v tekhnicheskikh voprosakh [On some differential equations of mathematical physics with applications in technical issues]. Leningrad: Izdatelstvo AN SSSR [in Russian].

2 Gantmaher, F.R., \& Krein, M.G. (1950). Ostsilliatsionnye matritsy i yadra i malye kolebaniia mekhanicheskikh sistem [Oscillatory matrices and nuclei and small vibrations of mechanical systems]. Moscow: Gosudarstvennoe izdatelstvo tekhniko-teoriticheskoi literatury [in Russian].

3 Golovati, Yu.D. (1992). Spektralnye svoistva kolebatelnykh sistem s prisoedinennymi massami [Spectral properties of vibrational systems with attached masses]. Trudy MMO, 54, $29-72$ [in Russian].

4 Bolotin, V.V. (1978). Vibratsiia v tekhnike [Vibration in Engineering]. Moscow: Mashinostroenie [in Russian].

5 Kollats, L. (1968). Zadachi na sobstvennye znacheniia [Eigenvalue tasks]. Moscow: Nauka [in Russian].

6 Low, K.H. (1998). On the eigenfrequencies for mass loaded beams under classical boundary conditions. Journal of Sound and Vibration, 215(2), 381-389.

7 Low, K.H. (1999). Comparisons of experimental and numerical frequencies for classical beams carrying a mass in-span. International Journal of Mechanical Sciences, 41, 1515-1531.

8 Low, K.H. (2001). On the methods to derive frequency equations of beams carrying multiple masses. International Journal of Mechanical Sciences, 43, 871-881.

9 Low, K.H. (2003). Natural frequencies of a beam-mass system in transverse vibration: Rayleigh estimation versus eigenanalysis solutions. International Journal of Mechanical Sciences, 45, 981-993.

10 Gürgöze, M., \& Batan, H. (1996). On the effect of an attached spring-mass system on the frequency spectrum of a cantilevered beam. Journal of Sound and Vibration, 195(1), 163-168.

11 Meirovitch, L. (2001). Fundamentals of vibrations. McGraw-Hill Book Co-Singapore. International Edition.

12 Vatulyan, A.O. (2007). Obratnie zadachi v mekhanike deformiruemogo tverdogo tela /Inverse problems in solid mechanics]. Moscow: Fizmatlit [in Russian].

13 Yong, L., \& Shunfeng, G. (2007). An analytical model for dynamic response of beam-column frames to impulsive ground excitations. Int. Journal of Solids and Structures, 44, 779-798.

14 Gladvell, G.M.L. (2008). Obratnye zadachi teorii kolebanii [Inverse problems of vibration theory]. Moscow: Reguliarnaia i khaoticheskaia dinamika [in Russian].

15 Younis, M.I. (2011). MEMS Linear and Nonlinear Statics and Dynamics. Springer New York Dordrecht Heidelberg London. 
16 Banerjee, J.R. (2012). Free vibration of beams carrying spring-mass systems? A dynamic stiffness approach. Computers and Structures, 104-105, 21-26.

17 Wang, Z., Hong, M., Xu, J., \& Cui, H. (2014). Analytical and experimental study of free vibration of beams carrying multiple masses and springs. J. Marine Sci. Appl. 13,32-40.

18 Morassi, A., \& Dilena, M. (2002). On point mass identification in rods and beams from minimal frequency measurements. Inverse Problems in Engineering, 10, 183-201.

19 Ahtyamov, A.M., \& Aupova, A.R. (2013). Identifikatsiia tochechnoi massy na sterzhne [Identifying a point mass on a bar]. Defektoskopiia, 49(10), 26-33 [in Russian].

20 Ahtyamov, A.M., \& Aupova, A.R. (2010). Diagnostika dvukh mass, sosredotochennykh na balke [Diagnosis of two masses concentrated on a balk]. Pribory i sistemy. Upravlenie, kontrol, diagnostika, 1, 42-4 [in Russian].

21 Kangujin, B.E., \& Nurakhmetov, D.B. (2015). Identifikatsiia sosredotochennoi massy i zhestkosti pruzhiny na sterzhne [Identification of the concentrated mass and stiffness of the spring on the rod]. Elektronnyi zhurnal «Tekhnicheskaia akustika», 9, 1-9 [in Russian].

22 Nurakhmetov, D.B., Jumabayev, S.A., \& Aniyarov, A.A. (2017). Inverse boundary problems for intermediate springs on a rod with geometrical symmetiry. Electronic Journal of Differential Equations, (33), 1-10.

23 Hunt, B.R., Lardy, L.J., Lipsman, R.L., Osborn, J.E., \& Rosenberg, J.M. (2009). Differential Equations with Maple. John Wiley \& Sons, Inc.

24 Nurakhmetov, D.B., Jumabayev, S.A., Aniyarov, A.A., \& Kussainov, R.K. (2020). Symmetric properties of eigenvalues and eigenfunctions of uniform beams. Symmetry, 12(2097), 1-13. 